\title{
Instruments for water quantity and quality management in the agriculture of Aragon (Spain)
}

José Albiac, Enrique Playán and Yolanda Martínez

\section{Summary}

Irrigated agriculture has always been relevant to the Aragonese society. The major expansion of irrigation took place during the XX century to promote economic growth and to improve farmers' social conditions in rural Spain. At present, maintaining irrigation in Aragon is still important because agriculture is linked to a strong agribusiness sector, and because irrigation contributes to avoid depopulation and territorial unbalances.

The traditional policy of developing new irrigated areas has been changed to irrigation modernization through investments in distribution networks and on-farm irrigation equipments. This new policy creates opportunities to introduce more profitable crops, conserve irrigation water and abate agricultural nonpoint pollution. Several alternatives open to irrigated agriculture are bioethanol and biodiesel technologies (which could provide a support price for grains), the expansion of profitable fruits and vegetables under drip irrigation, and the diversification of water using activities (animal farming, industries, residential areas and sport utilities).

Alternative measures to abate agricultural nonpoint pollution are examined in this paper. Modernizing irrigation structures leads to a large reduction of pollution, and introduces reasonable costs to farmers (in terms of their rent). Results also show that water pricing - advocated by the European Water Framework Directive - is a wrong policy in irrigation, because irrigation demand does not respond to prices and also because water pricing is not cost efficient to abate pollution.

Keywords: irrigated agriculture, modernization investments, water savings, nonpoint pollution abatement.

José Albiac, Researcher, Dept. Agricultural Economics, CITA-DGA, P.O.Box 727, 50080 Zaragoza, Spain.

maella@unizar.es

Enrique Playán, Researcher, Dept. Soil and Water, Estación Experimental de Aula Dei (CSIC), P.O.Box 202, 50080 Zaragoza, Spain.

playan@eead.csic.es

Yolanda Martínez, Assistant Professor, Dept. Economic Analysis, Economics School, University of Zaragoza, Gran Vía 2-4, 50004 Zaragoza, Spain.

yolandam@unizar.es

\section{Instruments for water quantity and quality management}




\section{in the agriculture of Aragon}

\section{Irrigated agriculture in Aragon: a historical perspective}

The agricultural sector in Aragon represents about 5\% of the regional GDP, and employs $7 \%$ of the working population. The Aragonese agriculture is linked to a important agribusiness sector, the second regional industrial activity (14\% of industrial production and $12 \%$ of industrial employment). The final agricultural production amounts to 2,900 M€, with a share of 1,100 M€ for agriculture and 1,300 M€ for livestock production. Agriculture is concentrated in the provinces of Zaragoza and Huesca, and the main crops in economic terms are grains, fruits, vegetables, forages, vineyards and olive trees. The main crops by province are barley, rice, alfalfa and fruits in Huesca; corn, vegetables and vineyards in Zaragoza; and olive trees in Teruel.

The average precipitation in Aragon reaches $500 \mathrm{~mm}$, although this figure is subjected to a large space and time variability. The flat lands in the central Ebro river depression receive little rain (about $250 \mathrm{~mm}$ ), with large year-to-year fluctuations. As a consequence, irrigation is required for most crops. Additional climatic limitations are hail and frost, which can result in incidental, relevant economic losses.

The development of irrigation has been a historical trait of the Aragonese society. Irrigation still constitutes a major tool for the development of rural communities. In fact,

the rural Aragonese irrigated areas show higher per capita income and have been more successful in maintaining the population and the demographic structure than the dryfarming areas. The irrigated area in Aragon is 446,000 ha, according to the 1999 agrarian census (INE 2002). The figure represents half of the irrigated area in the Ebro basin. Irrigation is used in one fourth of the cultivated land, and is equally distributed between the provinces of Huesca and Zaragoza. In the province of Teruel there are some 40,000 irrigated hectares, of which 25,000 ha are located in the Ebro basin. The counties with more irrigated land are Monegros (supplied by the Alto Aragón project), Cinco Villas (supplied by the Bardenas project), Zaragoza (supplied by the Imperial Canal), and Cinca Medio, Bajo Cinca and La Litera (supplied by the Aragon and Catalonia Project).

Water resources and irrigation development have been very important in Aragon for centuries. The bronze of Contrebia Belaisca (Botorrita) dated in 89 B.C. is an example of the relevance of water in Roman times. This archaeological piece documents the 
confrontation between the Iberic city of Salduie (Zaragoza) and the Basque city of Alaun (Alagón) for the Salduian water supply. The Roman Propretor of the Hispania Citerior province intervened in the settlement of this issue (Fatás and Beltrán 1997). A further example is the Almonacid de la Cuba reservoir, which required the tallest dam built in the whole of the Roman Empire. This reservoir supplied irrigation water to the Belchite agricultural fields through a complex network of canals and ditches. ${ }^{1}$

During the middle ages, irrigation was developed in the riparian lands of rivers Ebro, Jalón, Jiloca, Gállego and Huerva, whith the construction (between the XIII and XVI centuries) of the Camarera, Urdán, Candevanía and Rabal canals in the Gállego; the Centen canal in the Jalón, and the Tauste and Imperial canals in the Ebro. The construction of the Imperial canal was interrupted in the XVI century in the village of Garrapinillos; its extension to Zaragoza was not completed till the XVIII century.

The XIX century brought Spain a number of large, privately financed, hydraulic projects. While the urban supply projects of Madrid, Valencia, Gerona and Cartagena were characterized by success, private funding was not successful in irrigation projects. At the beginning of the $\mathrm{XX}$ century, public intervention was considered essential to the promotion of economic growth and social development in agrarian Spain. One of the promoters of these ideas was Joaquín Costa, who gathered social and political support to start complex irrigation projects such as Aragon and Catalonia, and Alto Aragón. These two irrigation projects, along with the more recent Bardenas project, were completed in their basic structures in the XX century, owing to large public investments.

The development of new irrigated land has slowed down in the last decades, showing area growth rates much smaller than reflected in the basic public policy documents: the Aragonese Water Agreement (Pacto del Agua) and the Hydrologic Plan of the Ebro Basin. Investment efforts currently focus on the modernization and rehabilitation of major water conveyance structures and on-farm irrigation systems. This change of policy reflects the fact that most water structures were obsolete and poorly maintained. The new policy has been cast in the Spanish National Irrigation Plan (SNIP; MAPA 2001).

The SNIP presents the following distribution of irrigation systems in Spain: 80\% surface irrigation, $18 \%$ sprinkler irrigation and 2\% drip irrigation. The most recent data of the agrarian census of 1999 already indicate a reduction in surface irrigation to 73\%, with sprinkler irrigation reaching 20\%, and drip irrigation jumping to 7\%. Figure 1 presents

Figure 1. Distribution of types of irrigation systems by county in Aragon.

\begin{tabular}{|r|l|}
\hline Teruel & \\
Bajo Aragón & Surface \\
Calamocha & $\square$ Sprinkler \\
Bajo Martín & $\square$ \\
Campo de Belchite & $\square$ \\
\hline
\end{tabular}


Source: National Statistics Institute (INE 2002) and Government of Aragon (2003).

irrigation systems per county in Aragon. Sprinkler irrigation is currently concentrated on the Monegros, La Litera and Bajo Cinca counties, adding up to half of the Aragonese sprinkler irrigated area. Most of the drip irrigation is located in Bajo Cinca, Valdejalón, Campo de Cariñena, La Litera and Somontano counties. Drip irrigation is associated to fruit and vegetable crops. To name a few examples, drip irrigation is used in Somontano for vineyards, in Bajo Cinca for pear trees and in Valdejalón for peach trees. Sprinkler irrigation is associated to field crops, such as corn and alfalfa.

Table 1 presents the quasi-rent for the most common crops in Aragon under irrigated and dryfarming conditions. The quasi-rent of irrigated fruits and vegetables exceeds that of field crops by a factor of five. While field crops can be surface or sprinkler irrigated, fruits and vegetables are typically drip irrigated. Several authors have reported moderate differences in irrigation efficiency among properly designed and maintained types of irrigation systems (Clemmens and Dedrick 1994, Hanson et al. 1995). As a consequence, the quasi-rent associated to the different irrigation systems becomes most

Table 1. Economic results of selected crops in Aragon in $€ /$ ha (2004). ${ }^{2}$ 


\begin{tabular}{|lcccc|}
\hline & Gross income & Subsidies & Farming costs & Quasi-rent \\
\hline Dry farming: & & & & \\
Wheat & 549 & 149 & 366 & 183 \\
Barley & 557 & 156 & 306 & 251 \\
Almonds & 500 & 223 & 293 & 207 \\
Olive trees (oil) & 424 & 100 & 268 & 156 \\
Vineyards (wine) & 3,271 & & 1,393 & 1,878 \\
\hline Irrigated: & & & & \\
Wheat & 897 & 254 & 520 & 377 \\
Barley & 757 & 234 & 512 & 245 \\
Corn & 1,766 & 468 & 991 & 775 \\
Alfalfa & 1,349 & & 682 & 667 \\
Green peas & 8,564 & & 6,497 & 2,067 \\
Tomato & 4,621 & & 2,079 & 2,542 \\
Peach trees & 5,859 & & 3,583 & 2,276 \\
Apple trees & 7,398 & & 2,650 & 4,748 \\
Pear trees & 4,376 & & 2,171 & 2,205 \\
\hline
\end{tabular}

Source: MAPA (2005).

important from a planning perspective. According to Table 1, the moderate extension of drip irrigation in Aragon does limit the economic return of irrigated agriculture.

Regarding irrigation efficiency, Causapé (2004) presented a review of the different studies of irrigation efficiency in the Ebro valley. Irrigation efficiency in Aragón is linked to the period of construction of the irrigation systems and to the technology available at the time. The following section describes the relationship between irrigation performance and irrigation technology in Aragon.

\section{Irrigation technology in Aragon}

Surface irrigation. Virtually all surface irrigation systems in Aragon were built at a time when there were no technological alternatives. Surface irrigation conveys water through the soil surface. As a consequence, the soil plays a major role in the performance of this irrigation system. Suited and unsuited soils were transformed into surface irrigation in periods when the Aragonese society had a high demand for agricultural goods. As a result, areas of high (90\%) and low irrigation efficiency (30\%) are separated in Aragón by as little as 300 m (Faci et al. 2000, Playán et al. 2000), with $50-60 \%$ being a reasonable regional average surface irrigation efficiency. Traditional surface irrigation systems were constructed by the farmers following trial and error procedures. 
The first approximations to surface irrigation design were introduced in the 1940's by the reclamation team led by engineer Francisco de los Ríos. For the first time, Diesel power was available for the construction of relatively large surface irrigation units. Blocked-end borders and level-basins (Walker and Skogerboe 1987) were constructed with typical areas of 1 ha, adapted to the needs of incipient farm mechanization. The design on-farm irrigation discharge was in the order of 40-80 L/s, lower-than-optimum, following the network capacity limitations imposed by budget restrictions. Mild field slopes (about $0.0005 \mathrm{~m} / \mathrm{m}$ ) were introduced to accelerate advance. This period of the XX century showed the largest increase in surface irrigated area, with reclaimed land being granted to new farmers at a rate of 4 (1940s) to 20 (1970s) ha per person.

Irrigation efficiency in Aragon is strongly associated to soil type and geomorphology (Lecina et al. 2005). Alluvial plains located at high geomorphologic positions often have shallow, coarse, stony soils. These soils show irrigation efficiencies typically below $50 \% \mathrm{t}$. The rapid internal drainage of these soils results in very good yields, but large deep percolation losses. On the contrary, soils developed in low geomorphologic positions are deep and fine-textured. Surface irrigation efficiency in these soils often surpasses $70 \%$. The subsurface flow resulting from low efficiency at the alluvial plains often leads to water logging and salinity build-up at these soils.

The vast majority of surface irrigation projects lacked internal regulation reservoirs. As a result, crop production was exposed to the uncertainties introduced by canal breakages. Additionally, irrigation water was delivered to the farmers $24 \mathrm{~h}$ a day. This extended working schedule posed a serious threat to irrigation sustainability as soon as industrial workers started to see their salaries rise and their working hours shrink. The introduction and generalization of laser guided land levelling in the 1980s resulted in increased efficiency, faster irrigation operation and improved crop yields (Playán et al. 1996). However, the decrease in agricultural employment following Spain's entry into the European Union in 1986 introduced additional challenges to this irrigation system.

Sprinkler irrigation. Pressurized irrigation started to be regionally relevant by the 1970s. Following a world-wide pattern, the first developments in sprinkler irrigation involved high pressure impact sprinklers (hand move) and side rolls. One or two decades later, solid-sets and (less frequenly) pivots were the two sprinkler systems remaining in Aragon. The small land tenure, the irregular plot geometry and the undulations of the soil surface have led to the generalization of solid-sets, a system 
which is generally considered too expensive to cultivate field crops. Only large plots, generally in new irrigation developments, enjoy the benefits of pivot irrigation: low cost and more uniform water application.

The major regional challenge for sprinkler irrigation is wind speed (Keller and Bliesner 1990, Tarjuelo 1995). With many Aragonese areas showing year round wind averages of 2 and $3 \mathrm{~m} / \mathrm{s}$, selecting adequate (low-wind) timing for sprinkler irrigation becomes a primary task for water- and energy-aware farmers. In fact, wind speed decreases uniformity (in solid sets) and increases wind drift and evaporation losses (in all sprinkler systems). As a consequence, irrigation efficiency and crop yield can be seriously limited (Dechmi et al. 2004, Playán et al. 2005, Zapata et al. 2007). Cuenca (1989) estimated an average solid-set efficiency in windy areas of about 67\%. Adequate design, the use of wind-resistant sprinklers and proper management at the collective and on-farm levels often lead to efficiencies beyond 80\% under windy Aragonese conditions.

In the last decades most of the area transformed to sprinkler irrigation was previously surface irrigated. Although sprinkler irrigation systems show higher efficiency than surface irrigation systems, efficiency is usually not the driving force for farmers facing irrigation modernization. Automation and labor reduction are the most relevant factors in an area where water scarcity has not yet reached generalized dimensions neither in space nor in time. Sprinkler irrigation systems have allowed farmers to increase the dimension of their field crop operations, thus accommodating the continuous decline in crop profitability. This will be particularly important in the near future, as part of farmers' reaction to the decoupling of European Union subsidies from crop activities, and the introduction of the unique payment in 2006.

Projects modernizing from surface to sprinkler irrigation usually have two components: a collective pressurized network and on-farm irrigation equipment. Financing schemes have been designed by both the Spanish and the Aragonese Governments, so that farmers do not have to make down payments, and just make yearly paybacks to cooperating banks for a period of 25 to 50 years. The yearly payback of a sprinkler irrigation modernization corresponds to abut two tons of maize per hectare (including modernization subsidies). The reliable water supply, increased uniformity and more frequent irrigation resulting from sprinkler irrigation can increase yield by more than two tons per hectare, with the additional advantages of reducing 
labor requirements and increasing the technological profile of the operator. Both factors add to irrigation sustainability. The financing scheme includes a contribution of the public administrations (Aragonese, Spanish and European), applied to the collective network. These public funds are diverted from rural development programs, owing to the proven capacity of irrigation to bring opportunities to rural societies. Public administrations have additional interests in the modernization process, such as water conservation and water quality improvement.

Drip irrigation. Drip irrigation in Aragon is linked to the important fruit production sector and to the less relevant sector of industrial horticulture. In both cases drip irrigation has emerged as a technological solution to attaining high yields, controlling plant growth and accurately applying agrochemicals. The introduction of Regulated Deficit Irrigation (RDI) and related techniques (Fereres and Goldhamer 2003; Goldhamer et al. 1999) in the fruit sector has given additional boost to this irrigation system. The costs associated to drip irrigation are often moderate in comparison with other production costs for fruits and vegetables. As a consequence, drip irrigation has been introduced even in the absence of specific public plans. In most cases drip irrigation has already replaced surface irrigation in areas traditionally devoted to the production of fruits and vegetables. While fruit production requires permanent irrigation systems, including both surface and subsurface layouts, the production of vegetables is often based on portable filtering and fertigation units connected to a collective network. Discardable drip lines are often installed in the same operation as the mulching plastic film. The introduction of drip irrigation in Aragon is primarily linked to crop agronomy and automation.

Water Users Associations. These institutions have been part of the Aragonese civil society since the onset of irrigation. Water Users Associations (WUAs) are regulated by the water law, and have a public-private nature. They receive water from canals and distribute water to the farmers, charging farmers for water use. The typical extension of an Aragonese WUA is between 1,000 and 10,000 ha. WUAs own and maintain collective distribution networks, and are the key actors in irrigation modernization, promoting projects, obtaining collective loans and exploiting the new pressurized networks. The daily management of WUAs in Aragon has been eased by the introduction in the present decade of the software Ador (Playán et al. 2007). This software is the fruit of institutional cooperation between researchers, the Regional 
Government, companies and WUAs. Eight years of research and development have led to the current situation, in which the software is used in half of the irrigated Aragonese land. Ador standardizes operation and management of WUAs, and creates a structured database containing information about water use. This information is the basis for the continuous improvement of collective water management. The Ador water bills also inform farmers of their current performance and establish comparisons with the rest of the farmers in the area.

WUAs undergoing irrigation modernization are facing significant challenges. One of the most important is the need to train their personnel to manage pressurized networks. In 2001 the Government of Aragon created the "Oficina del Regante”, an irrigation extension service to support technological needs. This office - currently part of the public Aragonese company SIRASA - supports the training of ditch riders and other WUA personnel in their new duties. One particular aspect of the new collective networks is currently creating relevant research and development demands: the telemetry and remote control system. Virtually all modernized WUAs incorporate this technology, which is currently underexploited. Telemetry permits to gather information about the network status, including water meter readouts and pressure distributions. Remote control allows operation of hydrant valves from the WUA office. WUAs find these applications potentially useful but lack the tools and human resources to apply them.

\section{Modernization of irrigation systems in Aragon: investments and opportunities}

The Spanish National Irrigation Plan (SNIP) reports that in Aragon there are 172,000 ha irrigated from unlined ditches and 51,000 ha irrigated from poorlymaintained concrete lined ditches. The SNIP proposes to switch from surface to pressurized (sprinkler and drip) irrigation in a total of 67,000 ha. Other specific modernization actions are planned in some $80 \%$ of the total irrigated area in Aragon (368,000 ha). The goal is to complete actions in a total of 190,000 ha by 2008, including the modernization of 142,000 ha and the construction of 48,000 new irrigated hectares. Most of these new irrigation developments derive from the completion of ongoing irrigation projects. Some of them have been in construction for a century now, like the 
Alto Aragón (16,800 ha), Bardenas (6,100 ha), and Calanda-Alcañiz (2,400 ha) projects.

Table 2. Spanish National Irrigation Plan (SNIP) investments in Aragon.

\begin{tabular}{|lrrrrr|}
\hline & $\begin{array}{c}\text { Area } \\
\text { (ha) }\end{array}$ & $\begin{array}{c}\text { National govt. } \\
(\mathrm{M} €)\end{array}$ & $\begin{array}{c}\text { State } \\
\text { govt.(M€) }\end{array}$ & $\begin{array}{c}\text { Private } \\
\text { (M€) }\end{array}$ & $\begin{array}{r}\text { Total } \\
(\mathrm{M} €)\end{array}$ \\
\hline Planning target for 2008 & & & & \\
\hline Modernization & 142,000 & 83 & 83 & 167 & 333 \\
In execution & 26,000 & 99 & 99 & 60 & 258 \\
Social irrigation devel. & 21,000 & 51 & 51 & 31 & 133 \\
Total investment & 234 & 234 & 257 & 725 \\
\hline Executed by December 2005 & & & & 110 & 234 \\
Modernization & 58 & 66 & 30 & 117 \\
In execution & 42 & 45 & 3 & 12 \\
Social irrigation devel. & 0 & 9 & 143 & 363 \\
Total investment & & 100 & 120 & 143 \\
\hline
\end{tabular}

Source: MAPA (2001), and Government of Aragon (2006). The figures for public investments by the Ministry regarding irrigation projects in execution do not include 2005 data.

The SNIP has resulted in a major change over the traditional irrigation-expansion policy of the Government of Spain. The old policy led to an increase in the irrigated area from 1.0 to 3.5 Mha during the XX century. For the first time, priority has been given to the modernization of obsolete irrigation areas, characterized by requiring large investments. The SNIP document estimates that $730 \mathrm{M} €$ will be required to attain the abovementioned goals in Aragon, with 470 and $260 \mathrm{M} €$ of public and private investments, respectively (Table 2). The total investment can also be divided in $330 \mathrm{M} €$ for modernization and 390 M€ for new irrigation developments. These new developments include 26,000 ha required to complete old projects (260 M€) and 21,000 ha of social irrigation developments (130 $\mathrm{M€).}$

By the beginning of 2006 the degree of completion of the SNIP goals was relatively high for irrigation modernization. In fact, the total investments totalized $230 \mathrm{M} €$ vs. the 330 M€ compromised in the $\mathrm{SNIP}^{3}$. Regarding the investments for new irrigated areas, the objectives are far from being completed, with an investment of $120 \mathrm{M} €$ for the irrigated areas in execution (the goal was $260 \mathrm{M} €$ ) and $12 \mathrm{M} €$ for social irrigation developments (the goal was $130 \mathrm{M€}$ ). In addition to the SNIP, the Government of Aragon dedicated $7 \mathrm{M€}$ to the "Strategic Plan of the Low Ebro in Aragon" (PEBEA). This plan develops new irrigation lands in the riparian areas of the Ebro River, Southeast of Zaragoza.

The key idea about irrigation modernization is that this process permits to do new farming operations at reasonable economic and environmental costs. In fact, irrigation modernization has a potential to introduce more profitable crops, thus creating more rural 
wealth. Additionally, modernization will lead to reduced irrigation water demand (water conservation), and to lower non-point source pollution (nutrients and salts). The materialization of this potential often requires coordination of efforts by farmers and their associations, public administrations and the agribusiness. Four lines of action can be envisaged at this time.

The first opportunity is in field crops. The most optimistic piece of news for this sector in the last decade has been the increased oil prices. The widespread application of bioethanol and biodiesel technologies can link the price of agricultural grains to the price of oil, thus providing a support price for the sector. Aragon is well positioned for these products, with a large irrigation sector and a clear vocation for field crops. The production of clean energy in the Aragonese fields could gain social support for this economic activity. Apparently, this sector will soon absorb the production of a significant area of the traditional field crops grown in Aragon. This demand could help sustain the new sprinkler irrigated areas, probably reversing the decaying trend on the profitability of these crops. The irrigation of field crops will have to be fully automated in order to minimize labor requirements. A reduced number of farmers, with a high technological profile, will remain in this activity. As an example, the research performed by Uku (2003) about the prospects for modernization of the Bardenas Project shows that switching from surface to pressurized irrigation increases crop yield and net margin, with reduced water and Nitrogen demand. Additionally, deep percolation and salt and nitrate pollution was reduced.

The second opportunity is in fruit trees. Table 1 shows that profitability is clearly associated to drip irrigated crops (including fruit trees and vegetables). Unfortunately, most modernization projects are oriented towards sprinkler irrigation. Fruit trees require a relevant modification in farmers' production habits. Many specialties of fruit trees face years of low prices, and are threatened by labor scarcity and price. Large scale operation and commercialization have proven very important to this business. Opportunities have been created in the last decade by technological developments in vineyards and olive trees. The automation of harvesting has eliminated traditional restrictions to the extension of these crops, which have raised the economic profile of a number of counties in Aragon. From a hydrological perspective this is a very attractive option, since the crop water requirements of most fruit trees are between one third and one half of those characterizing corn and alfalfa. 
The third opportunity is in the production of vegetable crops, mostly for the industry. In the intensive farming sector in the Central East and South East of Spain, greenhouse and open field producers face problems derived from persistent pests (which would benefit from summer production breaks), and the quantity and quality of the water resources, which are currently limiting crop yield and quality. Agreements between these areas and Aragonese farmers focusing on summer season produce using the Eastern marketing structures would lead to mutual economic and environmental benefits (Aldanondo, 2004). The socio-economic traits of Aragon would require lowlabor crops, since it has so far been difficult to settle permanent farm workers in the region.

The fourth opportunity for irrigation modernization is in the diversification of water using activities in the rural sector. Many Aragonese WUAs are currently serving water for purposes other than agricultural irrigation. Animal farming, industries, residential areas and sport utilities are common destinations of water primarily diverted for irrigation. With irrigation being one of the pillars of rural development policies in both the Aragonese and Spanish Governments, having access to a dependable source of regulated and pressurized water in the rural world is an unmatched opportunity for many synergic activities. Since many of them will not be consumptive, alternative uses can happen in cascade, and the resulting added value can be much higher than initially foreseen.

Regarding the potential for water conservation related to irrigation modernization, the watershed-scale impact depends on the modifications in water demand and in the irrigation return flows. Several authors have stated that irrigation modernization will result in a severe reduction in return flows which may in turn affect water availability at the watershed scale. Playán and Mateos (2006) discussed the hydrological effects of modernization, and pointed towards a sizeable decrease of water resources at the watershed, due to the effects of improvements in irrigation adequacy and uniformity, reclamation of obsolete, abandoned irrigated areas, and intensification of the crops. In fact, the presence of crops like barley in the Aragonese irrigated lands can only be explained through the alleviation of water demand during the peak of summer. Even if water is not scarce, the old water conveyance networks lack the capacity to grow waterintense crops in all the irrigated area. Barley is due to be replaced by more yielding crops, or to be combined with corn or sunflower in double-cropping schemes. An 
increase in the area devoted to profitable and low water demanding crops (such as olive trees, vineyards and sweet fruits) could make this effect less obvious. In this line, Sumpsi et al. (1998) and Blanco (1999) showed concern about subsidizing irrigation modernization without revising water allocation. In their opinion, this could lead to using the conserved water to increase the crop area or to increase crop intensity, finally leading to increased water shortages.

In order to effectively save water, planners will have to control water allocation. Only if this policy leads to a reduced watershed evapotranspiration, water availability will increase at the watershed scale. The control of water allocation seems technically possible in the conditions of collective irrigation characteristic of the Ebro Valley. In other areas of Spain characterized by depleted and degraded water resources, profitable crops and individual water extraction and allocation, the control of water quantity and quality stands as a more challenging task.

\section{Managing water quantity and quality in irrigated agriculture}

Management of water resources in agriculture depends on institutional, political and

technological factors. The main current changes in management are driven by the European Water Framework Directive (WFD) and the Spanish National Irrigation Plan (SNIP). The WFD intends to reach the "good ecological status" of all surface, subsurface and coastal waters, through management at river basin level, limits on source pollution and standards on ambient pollution at water courses, and increases in water prices. The SNIP promotes investments in modernization through public subsidies. These technological innovations facilitate major reductions in nonpoint pollution and increased water conservation because of the higher efficiency of irrigation systems.

The emphasis of the WFD on source pollution limits and ambient standards, and on rising water prices are almost irrelevant in irrigation at present. In one hand, control of irrigation emissions at the source or at the ambient are very difficult to implement, and on top of that there is no biophysical information available to support the design of reasonable measures in the short term. On the other hand, water pricing is a good instrument to curb industrial and urban demand, but it is clearly incapable to allocate water in agriculture and quite inefficient in abating nonpoint pollution ${ }^{4}$. The reasons for 
this are: 1) the rigidity of irrigation water demand; and 2) the insignificant reduction of pollution achieved by raising prices (resulting in large losses in rent for farmers).

In this respect, the investments in advanced irrigation technologies currently undertaken by the Spanish administration are much more interesting than the WFD

Table 3. Water use by group of crops in Aragon.

\begin{tabular}{|l|c|c|}
\hline & Acreage (ha) & Water use $\left(\mathrm{hm}^{3}\right)$ \\
\hline Cereals, alfalfa, sunflower & 296.100 & 2.205 \\
\hline Vegetables & 6.700 & 37 \\
\hline Fruit trees & 53.660 & 284 \\
\hline Total & 356.460 & 2.526 \\
\hline
\end{tabular}

Source: Mema (2006).

approach, based on pollution limits and water pricing. Updating irrigation technologies does not guarantee the solution to all problems, since the high investment costs may induce dedication to more input-intensive and profitable crops. This more intensive production could eventually increase water demand and pollution loads, but it is obvious that technical innovations in irrigation systems facilitate the private and public control of water quantity and quality.

Thus, it is essential to search for policies not based in an unique measure, but on a combination of institutional, economic and command and control instruments. In the area of nonpoint pollution abatement, the focus of recent literature is on incentives based on the ambient pollution loads in water courses, which are measurable, in contrast with emission loads at the source (plots). These incentives are tax-subsidy mechanisms and group fines linked to an ambient pollution threshold, which have to incorporate also the strategic behavior of farmers or their response to measures.

Another important question for water quantity and quality management is the efficiency and administrative costs of implementing uniform or differentiated measures. Measures can be adapted to the spatial heterogeneity of plots and watersheds and the ensuing variability of biophysical processes of crop production and the transport and fate of pollutants. In practice, uniform measures lose efficiency, such as when water taxes are identical for all farmers, disregarding water scarcity and the pollution potential of irrigation districts, and also the different damage on aquatic ecosystems. While homogeneous measures ignore that social benefits and costs vary among groups of farmers, large differences may end questioning their legitimacy and making them politically unfeasible. 
The volume of water resources used by irrigated agriculture in Aragon is close to 2,500 $\mathrm{hm}^{3}$, of which 2,200 are used for cereals and alfalfa and 280 for fruit trees (Table 3). By irrigation system, $1,800 \mathrm{hm}^{3}$ are applied through surface irrigation, 700 through sprinkle irrigation, and 100 through drip irrigation (Table 4). Irrigation return flows are

Table 4. Water use and return flows by irrigation systems in Aragon.

\begin{tabular}{|l|c|c|}
\hline & Water use $\left(\mathrm{hm}^{3}\right)$ & Percolation $\left(\mathrm{hm}^{3}\right)$ \\
\hline Surface & 1,763 & 705 \\
\hline Sprinkle & 655 & 164 \\
\hline Drip & 107 & 11 \\
\hline Total & 2,525 & 880 \\
\hline
\end{tabular}

Source: Mema (2006).

close to $900 \mathrm{hm}^{3}$, carrying relevant loads of nitrates and other salts which pollute water courses. Yearly Nitrate pollution is estimated at around 19,000 t $\left(\mathrm{N}_{-} \mathrm{NO}_{3}\right)$, from Nitrogen fertilizers $\left(65,000 \mathrm{t} \mathrm{N}-\mathrm{NO}_{3}\right)$. Salinity pollution is around one million tons, mostly from the Flumen, Cinca and Arba basins.

Control of irrigation water quantity and quality in the middle Ebro basin is important to achieve the good ecological status promoted by the Water Framework Directive. The control instruments should be defined in the WFD Program of Measures by 2009, and implemented by 2012. In relation to the control of quantities, water management is decentralized since the Ebro Water Authority (Confederación Hidrográfica del Ebro) allocates the resource through concessions, and the WUAs manage the resource in practice. No significant expansion of irrigation acreage is foreseen in Aragon, since the projected new irrigated area is below 20,000 ha. The largest basin-wide irrigation development projects are those of Canal de Navarra (50,000 ha in Navarre) and Canal de Segarra-Garrigues (80,000 ha in Catalonia).

Pollution control from agriculture has been addressed in several studies (Orús et al. 2000 and 2006, Uku 2003, Martínez and Albiac 2004 and 2006, Mema 2006). The results presented in Figures 1 and 2 correspond to the work of Mema (2006), who analyzed abatement measures for Nitrate and salinity emission loads. The study covers 215 municipal districts in 21 counties with significant irrigation area.

The evaluated control measures include taxes and quantitative limits on water use and Nitrogen fertilization, taxes on emissions of nitrates and salinity, and investments to modernize irrigation systems. The evaluation consists in ranking the cost efficiency of 
these measures, comparing the pollution abatement of each measure and its impact on farmers' quasi-rent and social welfare.

The present situation or baseline reflects the observed production, with current quantities and prices of crops and the inputs water and Nitrogen fertilizer. Under the present situation, crop production activities in the 380,000 ha of irrigated area generate a 
Figure 1. Yearly Nitrogen emission loads in Aragon ( $\left.\mathrm{N}-\mathrm{NO}_{3}{ }^{\top}\right)$.

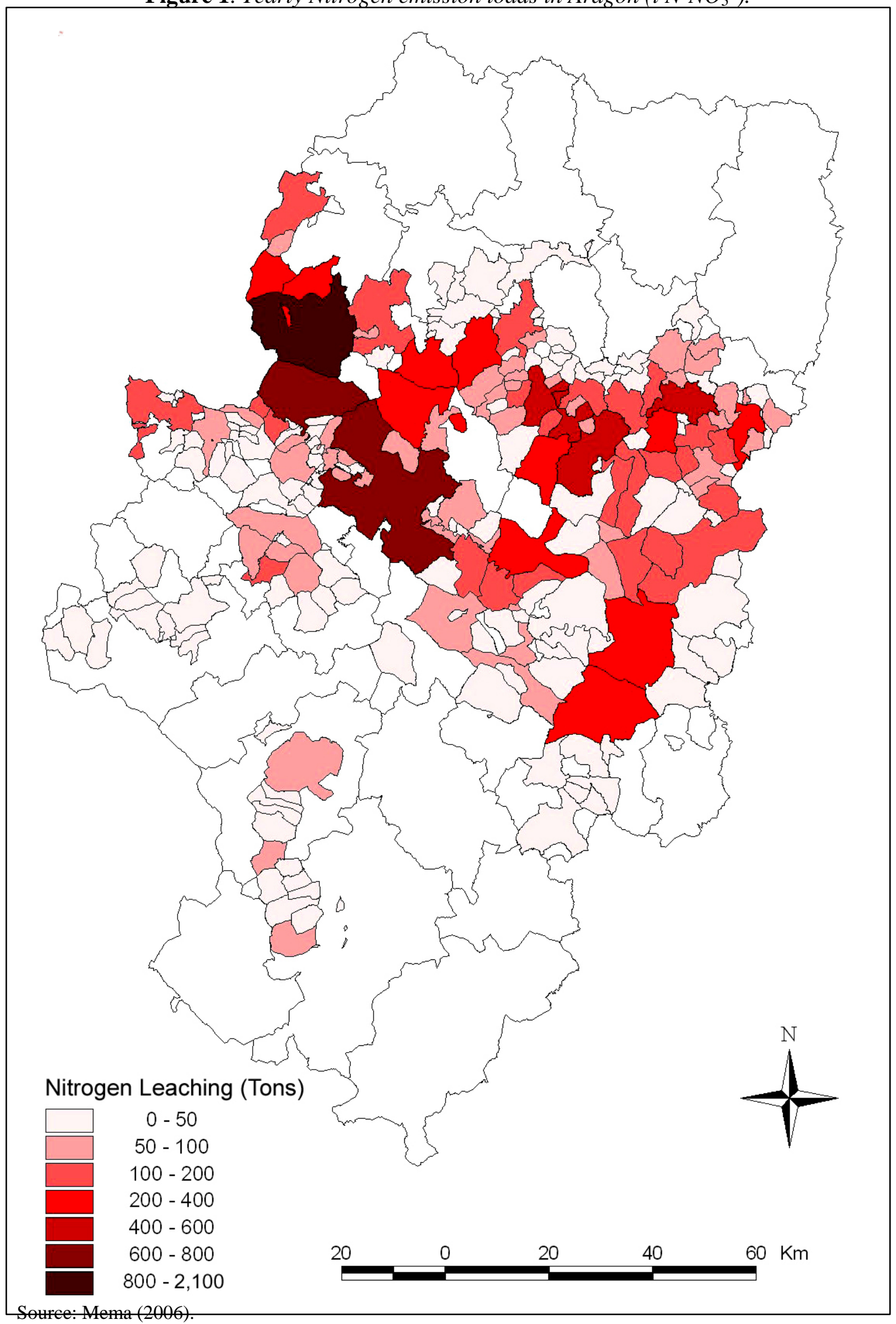


Table 5. Comparison of measures for pollution abatement.

\begin{tabular}{|l|c|c|c|c|c|c|}
\hline \multicolumn{1}{|c|}{ Measures } & $\begin{array}{c}\text { Quasi-rent } \\
\left(10^{6} €\right)\end{array}$ & $\begin{array}{c}\text { Water use } \\
\left(\mathrm{hm}^{3}\right)\end{array}$ & $\begin{array}{c}\text { Nitrogen use } \\
(\mathrm{t})\end{array}$ & $\begin{array}{c}\text { Percolation } \\
\left(\mathrm{hm}^{3}\right)\end{array}$ & $\begin{array}{c}\text { Nitrogen } \\
\text { leaching (t) }\end{array}$ & $\begin{array}{c}\text { Salinity load } \\
(\mathrm{t})\end{array}$ \\
\hline Present situation & 458 & 2,430 & 64,900 & 864 & 18,610 & $1,039,200$ \\
\hline Water tax & & & & & & \\
$0,045 € / \mathrm{m}^{3}$ & 372 & 2,060 & 60,710 & 723 & 14,450 & 796,500 \\
$0,075 € / \mathrm{m}^{3}$ & 329 & 1,820 & 58,250 & 627 & 12,000 & 643,300 \\
\hline Nitrogen tax & & & & & & \\
$0,3 € / \mathrm{kg}$ & 437 & 2,390 & 57,150 & 849 & 17,000 & $1,018,100$ \\
$0,6 € / \mathrm{kg}$ & 422 & 2,370 & 50,050 & 840 & 15,180 & $1,003,800$ \\
\hline Water limit (-25\%) & 364 & 1,700 & 44,090 & 576 & 12,470 & 672,000 \\
\hline Nitrogen limit & 441 & 2,330 & 46,820 & 815 & 13,660 & 970,700 \\
\hline Taxes on emissions & 399 & 2,170 & 55,520 & 750 & 14,360 & 779,400 \\
\hline Modernization & 429 & 2,160 & 54,130 & 525 & 11,580 & 543,700 \\
\hline
\end{tabular}

Source: Mema (2006).

quasi-rent close to $460 \mathrm{M} €$ (Table 5). Water use is $2,400 \mathrm{hm}^{3}$ with percolation close to $900 \mathrm{hm}^{3}$, and the amount of Nitrogen fertilizer is 65,000 t, with Nitrogen emissions around 19,000 t. Salinity loads are estimated at one million tons ${ }^{5}$. Average nitrate concentration in water returns is estimated at $96 \mathrm{mg} / \mathrm{l}$, while the average salinity concentration is around $1,200 \mathrm{mg} / \mathrm{l}$.

Nitrate and salinity emission loads from the 215 municipal districts studied are presented in Figures 1 and 2. Within the study area, large Nitrogen emission loads correspond to the Arba (3,900 t) and Cinca (3,300 t) basins, while large salinity loads correspond to the Flumen (332,000 t) and Cinca (241,000 t) basins.

From the point of view of farmers, the more advantageous measures are limits on Nitrogen fertilization, investments to modernize irrigation systems, or a moderate tax on Nitrogen fertilizer: the fall of quasi-rent under all these measures is below $30 \mathrm{M} €$ (-7\%). Limiting Nitrogen fertilization considerably abates Nitrogen leaching, but the reduction on salinity loads is negligible. A moderate tax on fertilizer slightly reduces the load of pollution emissions. On the other hand, irrigation modernization is the measure attaining the largest pollution abatement. The more detrimental measures for farmers are increasing water prices or limiting irrigation water, which reduced quasirent by $130 \mathrm{M} €(-30 \%)$.

These results are very relevant for the design of the Program of Measures of the WFD. Results show that the water pricing instrument advocated by the Water Framework Directive is not adequate to abate Nitrogen pollution. Other measures stemming from the WFD are more appropriate in the irrigation context, such as limits 
Figure 2. Yearly salinity emission loads in Aragon (t).

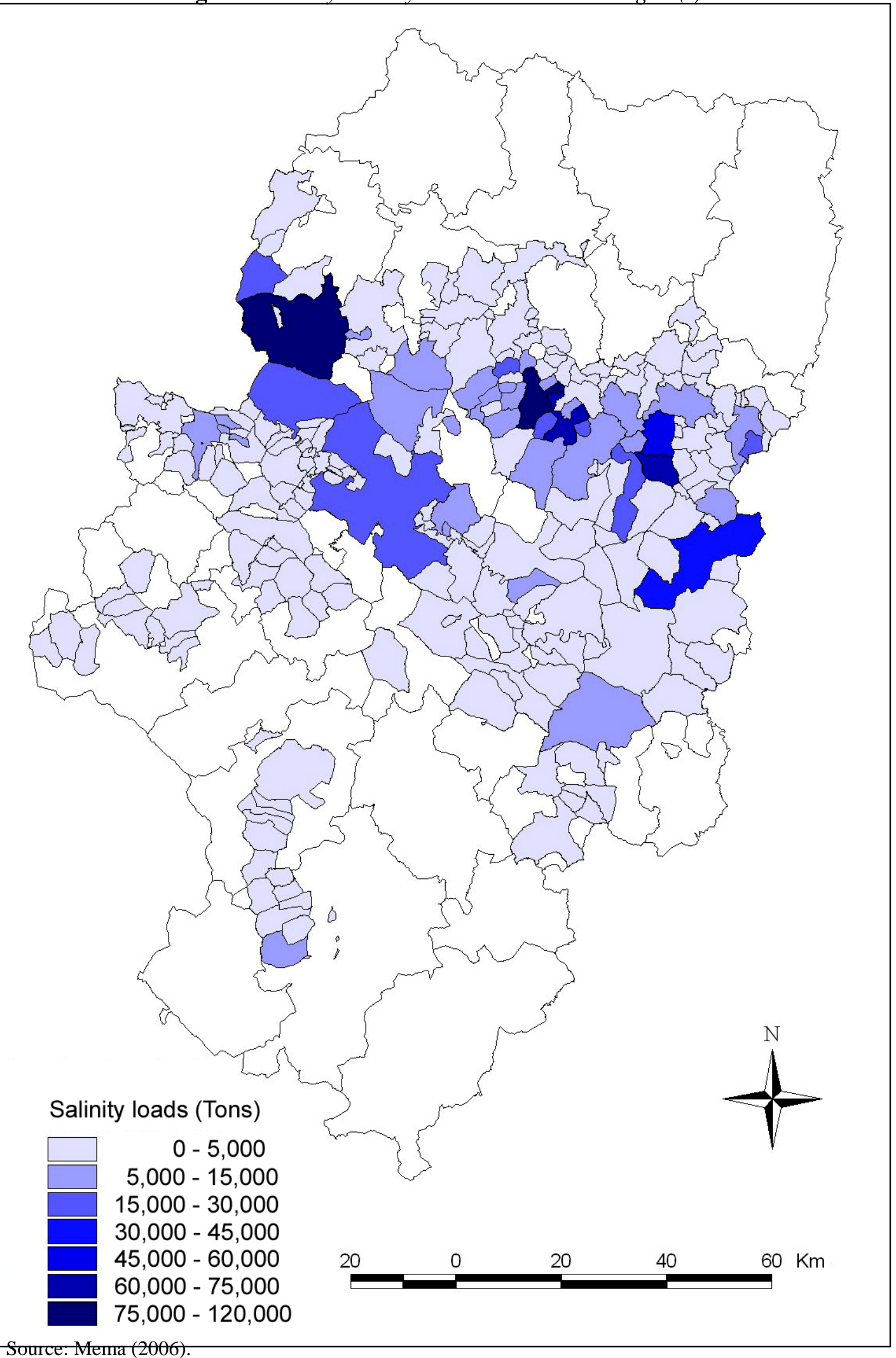


on surface and subsurface water extractions, limits on pollution at the source (plots) or standards on ambient pollution (river courses). Rising water prices is a meaningful measure for urban and industrial demand, because demand responds to prices and water savings are achieved. Irrigation demand does not respond to prices and water pricing is not a cost efficient measure to abate pollution ${ }^{6}$. Since water pricing is not a good measure for water allocation or for quality improvement, farmers are right in opposing large rises in water prices. However, a minimum price level is required to ensure proper water use and to disengage water from the "free good" image that characterized previous times.

Limiting Nitrogen fertilization reduces nitrate pollution, but not salinity loads. Modernizing irrigation systems is a very interesting measure, because it attains the larger pollution abatement with a moderate cost to farmers in terms of quasi-rent. Modernization reduces substantially the use of the inputs water and fertilizer, abates nitrate emission loads by 7,000 t, and cuts salinity emissions by half million tons.

\section{Summary and conclusions}

Irrigation has been important throughout the history of Aragon, especially during the last one hundred and fifty years. In present-day Aragon, irrigation has lost importance due to the transformation of the traditional agrarian society into a new society based on industry and services. However, maintaining irrigation in Aragon is still important because agriculture is linked to a strong agribusiness sector, and because irrigation contributes to articulate the territory, avoiding the problems of depopulation and territorial unbalances.

Surface irrigation is the major irrigation system in Aragón, built at a time when there were no technological alternatives. Sprinkler irrigation was introduced in the last decades to take advantage of automation and labor reduction. Drip irrigation in Aragon is linked to fruit production and also to industrial horticulture. One important initiative resulting from the cooperation of Water User Associations and the public administration is the Ador software, currently used in half the irrigated land of Aragon. This software introduces good practice in district water allocation, therefore improving collective water management. 
The large-scale objectives of expanding irrigation in Aragon have been cut down. Current efforts focus on modernizing irrigation networks and on-farm irrigation systems. This change of policy seems adequate, since irrigation hardware was obsolete in most Aragonese irrigated areas. The Spanish and Aragonese Administrations are making large efforts to implement the investment goals of the Spanish National Irrigation Plan.

Modernization creates opportunities to introduce more profitable crops, promote water conservation, and abate nonpoint pollution from agriculture. Achieving these objectives is not an easy task, since the expansion of profitable crops requires coordination among public administrations, farmers organizations and the agribusiness sector. The initiatives in this direction are quite scarce, and most farmers seem to prefer alternatives based on traditional crops, whose profitability is often based on subsidies.

Several lines of action can be envisaged to protect the value of the Aragonese irrigation sector: the first one is based on field crops producing bioethanol or biodiesel. These technologies can link the price of agricultural grains to the price of oil, thus providing a support price for the sector. Their demand could help sustain the new sprinkler irrigated areas, probably reversing the decaying trend on the profitability of these crops. A second line is in fruit trees and vegetables associated to drip irrigation, although these crops require a significant modification in farmers' production habits, capital investments and technological innovation. A third line of action is diversification of water using activities such as animal farming, industries, residential areas and sport utilities.

Some experts indicate that modernizing irrigation systems may reduce flows in watersheds because the fall in irrigation return flows may be more important than the reduction in water demand. Without cutbacks in water concessions, farmers may use the resource in more demanding crops or in marginal irrigation areas, decreasing returns and water flows in the basin. While in the irrigated areas developed in Mediterranean riparian areas - based on individual wells - water allocation is difficult to control, in Aragon it is technically possible to ensure that irrigation modernization results in an adequate water balance. In fact, water concessions can be modulated by the basin authority to attain extraction and distribution goals through the systems of dams and canals.

Finally, results comparing several measures for agricultural nonpoint pollution control are presented. An important finding is that irrigation modernization leads to a 
substantial abatement of pollution. This is the measure showing lowest costs to farmers in terms of quasi-rent, and attaining the largest reduction in both nitrate and salinity emissions. The increase in water prices advocated by the Water Framework Directive is a wrong policy for the irrigation sector. Rising water prices is an adequate measure for the industrial and urban sectors, and will contribute to address the problems of nonMediterranean countries. Water demand in irrigation does not respond to prices, and furthermore water pricing is not cost efficient to curb pollution. According to these results, decision makers should oppose water price increases to farmers, since the policy has proven to be inadequate to allocate water in irrigation, and ineffective to improve the quality of water resources.

\section{References}

Albiac J., Y. Martínez and J. Tapia. 2006. Water quantity and quality issues in Mediterranean agriculture. In Water and Agriculture: Sustainability, Markets and Policies. OECD. Paris.

Aldanondo A. 2004. Propuesta de investigación sobre las posibilidades de desarrollo de la horticultura intensiva en la Comunidad Autónoma de Aragón. Documento de Trabajo. Universidad Pública de Navarra. Pamplona, Spain

Arenillas M. 2002. Obras hidraúlicas romanas en Hispania. Artículo presentado en el Primer Congreso sobre las Obras Públicas Romanas. Mérida, Spain. http://traianus.rediris.es/textos/hidraulicas.htm

Blanco M. 1999. La economía del agua: análisis de políticas de modernización y mejora de regadíos. Tesis Doctoral. Universidad Politécnica de Madrid. Madrid, Spain.

Bosworth B., G. Cornish, C. Perry and F. van Steenbergen. 2002. Water Charging in Irrigated Agriculture. Lessons from the Literature. Report OD 145. HR Wallingford. Wallingford.

Causapé J. 2004. Eficiencia e impacto ambiental de los regadíos de la cuenca del Ebro. Documento Interno. Confederación Hidrográfica del Ebro. Zaragoza, Spain

Cornish G., B. Bosworth, C. Perry and J. Burke. 2004. Water charging in irrigated agriculture. An analysis of international experience. FAO Water reports $\mathrm{N}^{0} 28$. FAO. Roma.

Cornish G. and C. Perry. 2003. Water Charging in Irrigated Agriculture. Lessons from the Field. Report OD 150. HR Wallingford. Wallingford.

Clemmens A. and A. Dedrick. 1994. Irrigation techniques and evaluations. In K. Tanji and B. Yaron (eds.) Adv. series in agricultural sciences. Springer-Verlag. Berlin.

Cuenca R. 1989. Irrigation system design: an engineering approach. Prentice-Hall. Englewood Cliffs. New Jersey.

Dechmi F., E. Playán, J. Cavero, A. Martínez-Cob and J. Faci. 2004. A coupled crop and solid ser sprinkler simulation model: II. Model application. Journal of Irrigation and Drainage Engineering, ASCE 130(6): 511-519.

Faci J., A. Bensaci, A. Slatni and E. Playán. 2000. A case study for irrigation modernisation: I. Characterisation of the district and analysis of water delivery records. Agricultural Water Management 42:313-334. 
Fatás G. and M. Beltrán. 1997. Historia de Zaragoza. Volumen 1. Salduie, ciudad ibérica. Ayuntamiento de Zaragoza-Caja de Ahorros de la Inmaculada. Zaragoza.

Fereres E. and D. Goldhamer. 2003. Suitability of stem diameter variations and water potential as indicators for irrigation scheduling of almond trees. Journal of Horticultural Science \& Biotechnology 72 (2): 139-144.

Goldhamer D., E. Fereres, M. Mata, J. Girona and M. Cohen. 1999. Sensitivity of continuous and discrete plant and soil water status monitoring in peach trees subjected to deficit irrigation. Journal of the American Society of Horticultural Science 124(4): 437-444.

Government of Aragon. 2003. Base de datos 1T de superficie de cultivos por término municipal 1987-2002. Consejería de Agricultura. DGA. Zaragoza.

Government of Aragon. 2006. Resumen de Actuaciones 2000-2005 del Plan Nacional de Regadíos. Programas de Consolidación y Mejora, y de Inversión en Nuevos Regadíos. Documento Interno. Consejería de Agricultura. DGA. Zaragoza.

Hanson B., W. Bowers, B. Davidoff, D. Kasapligil, A. Carvajal and W. Bendixen. 1995. Field performance of microirrigation systems. Microirrigation for a changing world: Conserving resources/Preserving the environment. Proc., Fifth Int'l. Microirrigation Congress. Orlando.

INE, Instituto Nacional de Estadística. 2002. Censo Agrario 1999. INE. Madrid, Spain.

Keller J. and R. Bliesner. 1990. Sprinkle and trickle irrigation. Van Nostrand Reinhold. New York.

Lecina S., E. Playán, D. Isidoro, F. Dechmi, J. Causape and J. Faci. 2005. Irrigation evaluation and simulation at the irrigation district V of Bardenas (Spain). Agricultural Water Management 73(3): 223-245.

MAPA, Ministerio de Agricultura, Pesca y Alimentación. 2001. El Plan Nacional de Regadíos. Horizonte 2008. MAPA. Madrid.

MAPA, Ministerio de Agricultura, Pesca y Alimentación. 2005. Análisis de la economía de los sistemas de producción. Resultados técnico-económicos de explotaciones agrícolas de Aragón en 2004. Subsecretaría de Agricultura, Pesca y Alimentación. MAPA. Madrid.

Martínez Y. and J. Albiac. 2004. Agricultural pollution control under Spanish and European environmental policies. Water Resources Research 40(10), doi:10.1029/ 2004 WR003102.

Martínez Y. and J. Albiac. 2006. Nitrate pollution control under soil heterogeneity. Land Use Policy 23(4): 521-532.

Mema M. 2006. Las políticas de control de la contaminación difusa en el Valle medio del Ebro. Tesis Doctoral. Departamento de Estructura, Historia Económica y Economía Pública. Universidad de Zaragoza. Zaragoza.

Orús F., D. Quílez and J. Betrán. 2000. El código de buenas prácticas agrarias (I): Fertilización nitrogenada y contaminación por nitratos. Informaciones Técnicas No 93. Servicio de Formación y Extensión Agraria. Dirección General de Tecnología Agraria. DGA. Zaragoza.

Orús F. (Coordinator). 2006. Fertilización Nitrogenada. Guía de Actulización. Informaciones Técnicas Número Extraordinario. Centro de Transferencia Agroalimentaria. Dirección General de Desarrollo Rural. DGA. Zaragoza.

Playán E., J. Faci and A. Serreta. 1996. Modeling microtopography in basin irrigation. Journal of Irrigation and Drainage Engineering, ASCE, 122(6), 339-347.

Playán E., A. Slatni, R. Castillo and J. Faci. 2000. A case study for irrigation modernisation: II. Scenario Analysis. Agricultural Water Management 42: 335-354. 
Playán E., R. Salvador, J. Faci, N. Zapata, A. Martínez-Cob and I. Sánchez. 2005. Day and night wind drift and evaporation losses in sprinkler solid-sets and moving laterals. Agricultural Water Management 76(3): 139-159.

Playán E. and L. Mateos. 2006. Modernization and optimization of irrigation systems to increase water productivity. Agricultural Water Management 80(1-3): 100-116.

Playán E., J. Cavero, I. Mantero, R. Salvador, S. Lecina, J. Faci, J. Andrés, V. Salvador, G. Cardeña, S. Ramón, J. Lacueva, M. Tejero, J. Ferri and A. Martínez-Cob. 2007. A database program for enhancing irrigation district management in the Ebro valley (Spain). Agricultural Water Management. In press.

Sumpsi J., A. Garrido, M. Blanco, C. Varela and E. Iglesias. 1998. Economía y política de gestión del agua en la agricultura. Mundi-Prensa. Madrid.

Tarjuelo J. 1995. El riego por aspersión y su tecnología. Mundiprensa. Madrid.

Uku S. 2003. Análisis económico y medioambiental de los sistemas de riego: una aplicación al regadío de Bardenas. Tesis Doctoral. Departamento de Estructura, Historia Económica y Economía Pública. Universidad de Zaragoza. Zaragoza.

Walker W. and G. Skogerboe. 1987. Surface irrigation. Theory and practice. PrenticeHall. Englewood Cliffs. New Jersey.

Zapata N., E. Playán, A. Martínez-Cob, I. Sánchez, J. Faci and S. Lecina. 2007. From on-farm solid-set sprinkler irrigation design to collective irrigation network design in windy areas. Agricultural Water Management. In press.

\footnotetext{
${ }^{1}$ Arenillas (2002) states that the tallest Roman dams were Almonacid de la Cuba (34 m)., Proserpina in Mérida (22 m), and Harbaqa in Palmira (Syria) and Cornalvo in Badajoz (both with $21 \mathrm{~m}$ ).

${ }^{2}$ Gross income includes farming income plus subsidies. Farming costs include direct costs (seeds, fertilizers, agrochemicals), machinery, hired labor, overheads and amortization. Quasi-rent is gross income minus farming costs. Tomato figures are based on 2000 data.

${ }^{3}$ Modernization investments amounting to $234 \mathrm{M} €$ are divided in a public investment of $124 \mathrm{M} €$ and a private investment of $110 \mathrm{M} €$. The public companies SIRASA (Goverment of Aragon) and SEIASA (Government of Spain) have channelled investments of $148 \mathrm{M} €$ (66 M€ public, $82 \mathrm{M} €$ private) and 86 M€ (58 M€ public, 28 M€ private).

${ }^{4}$ Cornish et al. (2004) review the literature and present several case studies in different countries. Results show that water allocation in irrigation can not be attained through the price mechanism, and also that water markets are more adequate although their introduction require enormous and long-lasting efforts. Martínez and Albiac (2004 and 2006) prove the inefficiency of water pricing to abate nitrate pollution.

${ }^{5}$ Not including gypsum.

${ }^{6}$ Albiac et al. (2006) discuss the reasons explaining the lack of response of demand to water pricing. Bosworth et al. (2002) show the evidence from the literature on this question, and Cornish y Perry (2003) look at the question from field experiments in several countries. Results form these two studies have been published by FAO (Cornish et al. 2004).
} 